\title{
Polycyclic Aromatic Hydrocarbons (PAH) and Phenolic Substances in Cold Smoked Sausages Depending on Smoking Conditions Using Smouldering Smoke
}

\author{
Alexander Hitzel \\ Analysis Division, Max Rubner-Institut (MRI) \\ E.-C.-Baumann-Str. 20, 95326 Kulmbach, Germany
}

Tel: 49-9221-803-208Ｅ-mail: alexander.hitzel@mri.bund.de

Margarete Pöhlmann

Analysis Division, Max Rubner-Institut (MRI)

E.-C.-Baumann-Str. 20, 95326 Kulmbach, Germany

Tel: 49-9221-803-208Ｅ-mail: margarete.poehlmann@mri.bund.de

Fredi Schwägele

Analysis Division, Max Rubner-Institut (MRI)

E.-C.-Baumann-Str. 20, 95326 Kulmbach, Germany

Tel: 49-9221-803-200Ｅ-mail: fredi.schwaegele@mri.bund.de

Karl Speer

Food Chemistry Department, Technical University of Dresden

Bergstr. 66, 01069 Dresden, Germany

Tel: 49-351-4633-2006_E-mail: karl.speer@chemie.tu-dresden.de

Wolfgang Jira (Corresponding author)

Analysis Division, Max Rubner-Institut (MRI)

E.-C.-Baumann-Str. 20, 95326 Kulmbach, Germany

Tel: 49-9221-803-313 E-mail: wolfgang.jira@mri.bund.de

Received: February 1, 2012

Accepted: February 17, 2012 Published: May 1, 2012

doi:10.5539/jfr.v1n2p45

URL: http://dx.doi.org/10.5539/jfr.v1n2p45

The research project was supported by the German Ministry of Economics and Technology (via AiF) and the FEI (Forschungskreis der Ernährungsindustrie e.V., Bonn). Project AiF $16460 N$ and the Förderergesellschaft für Fleischforschung e. $V$.

\begin{abstract}
The contents of polycyclic aromatic hydrocarbons (PAH) and phenolic substances in mini-salamis were investigated depending on cold smoking conditions (smouldering smoke). Three different smoke densities (light, medium, and intensive smoke) and ventilator velocities (750, 1500, and $3000 \mathrm{rpm}$ ) as well as wood chips of four different moisture contents $(12 \%, 19 \%, 24 \%$, and $30 \%)$ were tested in a total of 24 smoking experiments. During the smoking process, the concentrations of oxygen, carbon dioxide and carbon monoxide, the humidity and the
\end{abstract}


temperature in the smoking chamber as well as the smoke generation temperature were continuously determined. The chemical analysis included benzo[a]pyrene, PAH4, and six other PAHs with contents above $0.1 \mu \mathrm{g} / \mathrm{kg}$ as well as the phenolic substances guaiacol, 4-methylguaiacol, syringol, eugenol, and trans-isoeugenol. The smoke density had influence on the PAH contents. Sufficient amounts of phenolic substances (sum contents above 30 $\mathrm{mg} / \mathrm{kg}$ ) were detected in all the experiments.

Keywords: Polycyclic aromatic hydrocarbons, Phenolic substances, Mini-salamis, Smoking conditions, Smouldering smoke, GC/MS

\section{Introduction}

Polycyclic aromatic hydrocarbons (PAH) consist of two or more condensed aromatic carbon rings and are formed during the incomplete combustion of organic material (Smith, 1984). About 660 different compounds belong to the PAH group (Sander \& Wise, 1997), some of them showing carcinogenic properties (IARC, 1987; IARC, 2010). Due to the carcinogenic properties, the Scientific Committee on Food (SCF) recommended that the PAH contents in food should be "as low as reasonably achievable" in adherence to the so-called ALARA-principle (SCF, 2002). Furthermore, the Codex Alimentarius Commission recommended the investigation and the identification of optimal smoking conditions for minimizing PAH contents (CAC, 2008).

In a previous study (Pöhlmann et al., 2012) it was shown that a minimization of the PAH compounds in hot smoked sausages using glow smoke is possible. The most important parameter influencing the PAH contents was the smoke generation temperature, however, the ventilator velocity also had a noticeable influence on the PAH contents. Lowering the contents of the PAH compounds did not necessarily lead to a decrease in the amounts of phenolic substances which are of considerable importance for the organoleptic properties of smoked meat products (Bratzler et al., 1969; Kjallstrand \& Petersson, 2001) and show antimicrobial (Davidson \& Branden, 1981) and antioxidative (Toth, 1982; Wittkowski, 1985) properties.

The main objective of this study was to investigate the correlations between the PAH contents and the phenolic substances in raw sausages depending on cold smoking conditions using smouldering smoke. Within the group of PAH compounds the investigations did not only focus on benzo[a]pyrene $(\mathrm{BaP})$ as the EFSA had concluded that $\mathrm{BaP}$ was not a suitable indicator for the occurrence of PAHs in food, assessing that the sum of the four PAH compounds $\mathrm{BaP}$, chrysene (CHR), benzo[a]anthracene (BaA), and benzo[b]fluoranthene (BbF) (PAH4) was the most suitable indicator for PAHs in food (EFSA, 2008). New maximum levels for PAH4 in smoked meat products of $30 \mu \mathrm{g} / \mathrm{kg}(1 / 9 / 2012$ to $31 / 08 / 2014)$ and, later, of $12 \mu \mathrm{g} / \mathrm{kg}$ were established in Commission Regulation (EU) No 835/2011. Consequently, the contents of BaP and PAH4 and, additionally, the contents of the six other PAHs: benzo[c]fluorene (BcL), cyclopenta[c,d]pyrene (CPP), benzo[k]fluoranthene (BkF), benzo[j]fluoranthene (BjF), indeno[1,2,3-c,d]pyrene (IcP), and benzo[g,h,i]perylene (BgP) with contents above $0.1 \mu \mathrm{g} / \mathrm{kg}$ were considered in order to draw conclusions concerning the influence of the smoking parameters on the PAH contents.

Within the group of phenolic substances the dominant compounds guaiacol, 4-methylguaiacol, syringol, eugenol, and trans-isoeugenol were analyzed. The smoking experiments were performed with mini-salamis having the advantage of a large surface/mass ratio and a short ripening period. Since it was shown that the PAH contents increased with smoking time (Djinovic et al., 2008a; Djinovic et al., 2008b), the same smoking time was selected for all the smoking experiments. All in all, 24 smoking experiments were performed.

\section{Materials and Methods}

\subsection{Preparation of mini-salamis}

The mini-salamis were made of $76.9 \%$ frozen pork, $19.4 \%$ frozen back fat, $2.4 \%$ salt (containing $0.4 \%$ sodium nitrite $\left(\mathrm{NaNO}_{2}\right)$ ), 0.4\% glucose, $0.4 \%$ spice mix "Salami Mild French-Style" from Raps (Kulmbach, Germany), and at least $2.5 \times 10^{10}$ active microorganisms "Optistart Sprint" from Raps (Kulmbach, Germany). Due to raising activity of undesirable microorganisms in less smoked mini-salamis, the content of starter cultures was increased to a minimum of $10^{11}$ active microorganisms (for smoking experiments $6 \mathrm{a}, \mathrm{b}$ to $12 \mathrm{a}, \mathrm{b}$ ) and $0.4-0.5 \%$ glucono delta-lactone (GDL) were added (for smoking experiments 8 a, b to $12 \mathrm{a}, \mathrm{b}$ ). Sheep casings made from the sub-mucosa of the small intestine were used. A batch weighed approx. $8 \mathrm{~kg}$ and was used for two smoking experiments (first smoking experiment $=\mathrm{a}$; second smoking experiment $=\mathrm{b}$ ) and as matrix blank.

\subsection{Smoking experiments}

Before smoking, the mini-salamis were dried and cured for two days in a climatic chamber at a temperature of $22{ }^{\circ} \mathrm{C}$. On the third day they were smoked in a T 1900 Ratio smoking chamber combined with an RZ 325 smoke generator from Fessmann (Winnenden, Germany) at $22{ }^{\circ} \mathrm{C}$ for $30 \mathrm{~min}$, using beech wood chips (size: 4.0 - 12.0 
mm; KL 2-16) obtained from J. Rettenmaier \& Söhne (Rosenberg, Germany). The smoke generator coupled with the smoking chamber was able to produce three different smoke densities: intensive, medium, and light smoke. The process of the smoke generation started with fresh air, which was injected into a TOP-device at a rate of 40 $\mathrm{m}^{3} / \mathrm{h}$, where the volume of air was split into smouldering air and additive air. The smouldering air flowed to the smouldering area through a tube and caused the beech wood chips to glow. The inlet of smouldering air depended on the additive air parameters. The dilution of smoke also depended on the additive air which was led to the ash area via two tubes of different inner diameters. Opening both tubes resulted in light smoke. Medium smoke was produced by closing the tube with the smaller inner diameter while opening the tube with the larger diameter. This way, intensive smoke was generated by opening the tube with the smaller inner diameter while closing the tube with the larger inner diameter to obtain less dilution. The ventilator velocity in the smoking chamber was also variable between 750,1500 , and $3000 \mathrm{rpm}$. The smoking time was set to $30 \mathrm{~min}$ for each smoking experiment. The moisture of the wood chips was only measured but not changed for experiments $1 \mathrm{a}, \mathrm{b}$ to $9 \mathrm{a}, \mathrm{b}$ and averaged out at about $12.0 \%$. For the experiments $10 \mathrm{a}, \mathrm{b}$ to $12 \mathrm{a}, \mathrm{b}$ the moisture of wood chips was adjusted by adding distilled water. The changes in the smoke density, ventilator velocity and moisture of the wood chips resulted in 24 experiments (12 experiments performed as duplicates) (Table 1). After two additional days of drying and curing at $20^{\circ} \mathrm{C}$, about $1 \mathrm{~kg}$ of the mini-salamis were homogenized in a $5 \mathrm{~L}$ bowl chopper and stored in the dark at $-18{ }^{\circ} \mathrm{C}$ until chemical analysis.

\subsection{Measurement of smoke generation temperature and gases}

A NiCrNi sensor from Testo (Lenzkirchen, Germany) was positioned 2-3 $\mathrm{cm}$ above the heating rod grooves in the smoke generator for measuring the temperature of the wood combustion. The data were collected by a 350-S flue gas analyzer from Testo (Lenzkirch, Germany). For monitoring the smoke composition during the smoking process, the smoke-air mixture was received from the smoking chamber at a flow rate of about $1 \mathrm{~L} / \mathrm{min}$. It passed through a tube (length: approximately $1 \mathrm{~m}$; inner diameter: $13 \mathrm{~mm}$ ), a wash bottle (filled with $400 \mathrm{~mL}$ distilled water) and finally a condensate trap before being analyzed by the flue gas analyzer mentioned above. The concentrations of carbon dioxide and oxygen were measured in volume percent while the concentrations of carbon monoxide were measured in ppm. A data point was created by averaging five values of every second recorded gas concentration.

\subsection{Measurement of $\mathrm{pH}$ value}

The $\mathrm{pH}$-value of the mini-salamis was measured at the end of the ripening period using a Portamess Type $911 \mathrm{pH}$ meter from Knick (Berlin, Germany).

\subsection{Sensory evaluation}

The production of the mini-salamis required five days. The sensory evaluation was performed after an additional two days of storage at $4{ }^{\circ} \mathrm{C}$. The following aspects were evaluated: color, texture, odor and flavor. If a sample fulfilled the expectations of a panelist, 0 points were given to a category. For deviations from the expectations positive points for "too high" and negative points for "too low" were given. Five to six panelists evaluated the mini-salamis.

\subsection{Reagents}

The solvents n-hexane, iso-octane, and ethylacetate were purchased from LGC Standards (Wesel, Germany) in Picograde ${ }^{\circledR}$ quality. The drying material used in the PLE cells (poly (acrylic acid), partial sodium saltgraft-poly (ethylene oxide), cross-linked, 90-850 $\mu \mathrm{m}$ ) was obtained from Sigma-Aldrich (Steinheim, Germany), and the glass microfiber filters were purchased from Büchi (Flawil, Switzerland). The extracts were filtered through 1.0 $\mu \mathrm{m}$ PTFE syringe filters purchased from Grace (Deerfield, USA) or $0.45 \mu \mathrm{m}$ PTFE OPTI-Flow syringe filters obtained from Wicom (Heppenheim, Germany). The GPC column was filled with Bio-Beads S-X3 (200-400 mesh) purchased from Bio-Rad Laboratories (Munich, Germany). The last clean-up step was performed by means of Supelclean ${ }^{\mathrm{TM}}$ LC-Si SPE Tubes, $6 \mathrm{~mL}(1 \mathrm{~g})$, obtained from Supelco (Bellefonte, USA). A standard mixture of the isotope labeled or fluorinated $\mathrm{PAH}$ i.e. benzo[a]anthracene- ${ }^{13} \mathrm{C}_{6}$, chrysene- $-{ }^{13} \mathrm{C}_{6}$, benzo[b]fluoranthene- ${ }^{13} \mathrm{C}_{6}$, benzo[k]fluoranthene- ${ }^{13} \mathrm{C}_{6}$, benzo[a]pyrene- ${ }^{13} \mathrm{C}_{4}$, indeno[1,2, 3-cd]pyrene- $\mathrm{d}_{12}$, benzo[g,h,i]perylene- ${ }^{13} \mathrm{C}_{12}$, and 5-fluorobenzo[c]fluorene was prepared in iso-octane, mixing the solutions of the single compounds purchased from LGC Standards $\left[\left({ }^{13} \mathrm{C}\right.\right.$ and ${ }^{2} \mathrm{H}$ labeled compounds) Wesel, Germany $]$ and the Biochemical Institute for Environmental Carcinogens [(fluorinated compounds) Grosshansdorf, Germany], respectively. The PAH recovery standard mixture consisted of benzo[a]anthracene- $\mathrm{d}_{12}$, benzo[a]pyrene- $\mathrm{d}_{12}$, and benzo[g,h,i]perylene- $d_{12}$ (LGC Standards, Wesel, Germany) in iso-octane. For the response factor calibration the reference standard PAH-Mix 183 containing all 15+1 EU priority PAHs obtained from Dr. Ehrenstorfer (Augsburg, Germany) was applied. 
The standards of guaiacol (2-methoxyphenol), 4-methylguaiacol (2-methoxy-4-methylphenol), syringol (2,6-dimethoxyphenol), eugenol (4-allyl-2-methoxyphenol), and isoeugenol (cis/trans; 2-methoxy-4-(1-propenyl)phenol) were obtained from Alfa Aesar (Karlsruhe, Germany). Isotope labeled ${ }^{13} \mathrm{C}_{6}$-guaiacol was obtained from LGC Standards (Wesel, Germany) and guaiacol- $\mathrm{d}_{4}$ from Dr. Ehrenstorfer $\mathrm{GmbH}$ (Augsburg, Germany). All phenolic standards were dissolved in ethyl acetate. Lithium chloride was purchased from J.T. Baker (Deventer, Netherlands), sodium sulphate and sodium hydrogencarbonate were both purchased from Merck (Darmstadt, Germany). Ethyl acetate was obtained from LGC Standards (Wesel, Germany) and diethyl ether from Acros organics (New Jersey, USA). BSTFA (N,O-bis(trimethylsilyl)trifluoroacetamide) was obtained from Supelco (Bellefonte, USA) and Hypersep Si SPE cartridges from Thermo Fisher Scientific (Bellefonte, USA).

\subsection{Analysis of PAH contents}

\subsubsection{Pressurized liquid extraction (PLE)}

Approx. $3 \mathrm{~g}$ of homogenized mini-salamis were mixed with an equal amount of the drying material poly(acrylic acid), partial sodium salt-graft-poly(ethylene oxide). The resulting material was transferred into $40 \mathrm{~mL}$ cells filled with $3 \mathrm{~g}$ drying material equipped with disposable glass-fiber filters. Then, $50 \mu \mathrm{L}$ of a PAH standard mixture containing isotope labeled $\left({ }^{13} \mathrm{C}\right.$ and $\left.{ }^{2} \mathrm{H}\right)$ and fluorinated PAH compounds was added as internal standard. After the addition of a further $9 \mathrm{~g}$ of drying material, the extraction was performed with a Speed Extractor E-916 from Büchi (Flawil, Switzerland) and n-hexane as solvent. Two static cycles were accomplished (operating conditions: $70{ }^{\circ} \mathrm{C}, 70 \mathrm{bar}$, static time $10 \mathrm{~min}$ and purge time $120 \mathrm{~s}$ ). The solvent of the extract was evaporated using a Multivapor P-12 from Büchi (Flawil, Switzerland; water bath: $40^{\circ} \mathrm{C}$ ).

\subsubsection{Gel permeation chromatography (GPC)}

The evaporated PLE extract was dissolved in $4.5 \mathrm{~mL}$ cyclohexane/ethylacetate $(1: 1, \mathrm{v} / \mathrm{v})$ and filtered through a polytetrafluoroethylene (PTFE) syringe filter of pore size $1 \mu \mathrm{m}$. The GPC column $(25 \mathrm{~mm}$ i.d.) was filled with $60 \mathrm{~g}$ Bio-Beads S-X3. The samples were eluted at a flow rate of $5 \mathrm{~mL} / \mathrm{min}$ applying cyclohexane/ethylacetate $(1: 1, \mathrm{v} / \mathrm{v})$. The GPC solvent was removed by a rotary evaporator. Afterwards, the eluate was dried in a nitrogen stream. The waste time was 0-36 min and the collect time 36-65 min. The dried GPC eluate was dissolved in 1 $\mathrm{mL}$ cyclohexane (Jira, 2004).

\subsubsection{Solid phase extraction (SPE)}

The samples were transferred onto silica gel SPE cartridges conditioned with $3 \mathrm{~mL}$ cyclohexane and eluted with $10 \mathrm{~mL}$ cyclohexane.

\subsubsection{Preparation for GC/MS analysis}

The dried SPE eluate was dissolved in $1 \mathrm{~mL}$ iso-octane and $50 \mu \mathrm{L}$ of the PAH-recovery standard mixture and transferred to a $1 \mathrm{~mL}$ tapered vial. The remaining sample was carefully concentrated in a nitrogen stream to about $50 \mu \mathrm{L}$ (Jira et al., 2008).

\subsubsection{Fast-GC/HRMS analysis}

Fast-GC/HRMS was performed using a Trace-GC chromatograph (ThermoFisher Scientific, Milan, Italy) equipped with a split/splitless injection port. A chromatographic separation of the PAHs (with the exception of a separation of CHR and triphenylene (TP)) was performed on a TR-50MS column (10 m x $0.1 \mathrm{~mm} \times 0.1 \mu \mathrm{m})$ (ThermoFisher Scientific, Bremen, Germany). Injection temperature was $260{ }^{\circ} \mathrm{C}$, injection volume $1.5 \mu \mathrm{L}$ (splitless). Helium with a constant flow of $0.6 \mathrm{~mL} / \mathrm{min}$ was used as carrier gas. The following temperature program was applied: isothermal at $140{ }^{\circ} \mathrm{C}$ for $1 \mathrm{~min}$, at $10{ }^{\circ} \mathrm{C} / \mathrm{min}$ to $240{ }^{\circ} \mathrm{C}$, at $5{ }^{\circ} \mathrm{C} / \mathrm{min}$ to $270{ }^{\circ} \mathrm{C}$, at $30{ }^{\circ} \mathrm{C} / \mathrm{min}$ to $280{ }^{\circ} \mathrm{C}$, at $4{ }^{\circ} \mathrm{C} / \mathrm{min}$ to $290{ }^{\circ} \mathrm{C}$, at $30{ }^{\circ} \mathrm{C} / \mathrm{min}$ to $315{ }^{\circ} \mathrm{C}$ and at $3{ }^{\circ} \mathrm{C} / \mathrm{min}$ to $330{ }^{\circ} \mathrm{C}$. The identification of the PAHs by GC/HRMS was performed using a sector mass spectrometer DFS (Thermo Fisher Scientific, Bremen, Germany) working in the electron impact (EI) positive ion mode, applying an electron energy of $45 \mathrm{eV}$. The temperature of the source and the transfer line was heated up to $280{ }^{\circ} \mathrm{C}$ and $300{ }^{\circ} \mathrm{C}$, respectively. The resolution of the MS was tuned to 8000 (10\% valley definition) (Ziegenhals et al., 2008).

\subsection{Analysis of phenolic compounds}

\subsubsection{Steam distillation and extraction}

The five phenolic compounds were determined using a modified method based on a previously published method (Pöhlmann et al., 2012). The smoked sausage was homogenized and $1 \mathrm{~g}$ of the mini-salamis was filled in an insert of an Antonacopoulos apparatus (Antonacopoulos, 1960; Toth, 1982). $10 \mu 1$ of internal standard $\left({ }^{13} \mathrm{C}_{6}\right.$-guaiacol; $0.1 \mathrm{mg} / \mathrm{mL}$ in ethyl acetate) and $50 \mathrm{~mL}$ aqueous $\mathrm{LiCl}$ solution $(30 \%)$ were added and boiled until 
$400 \mathrm{~mL}$ were distilled. With a $\mathrm{NaHCO}_{3}$ solution, the distillate was adjusted to $\mathrm{pH} 5$, extracted three times with $100 \mathrm{~mL}$ diethyl ether, and dried over $\mathrm{Na}_{2} \mathrm{SO}_{4}$. The solvent was removed with a rotary evaporator at $40{ }^{\circ} \mathrm{C}$ and 850 mbar.

\subsubsection{Solid phase extraction (SPE)}

The residue was dissolved in $1 \mathrm{~mL}$ ethyl acetate and applied to a conditioned silica gel SPE cartridge $(1 \mathrm{~g} / 6 \mathrm{~mL})$. The phenolic compounds were eluted with $6 \mathrm{~mL}$ ethyl acetate.

\subsubsection{Trimethylsilylation}

$10 \mu \mathrm{L}$ recovery standard (guaiacol- $\mathrm{d}_{4} ; 0.1 \mathrm{mg} / \mathrm{mL}$ in ethyl acetate) was added to the SPE-eluate. An aliquot of 1 $\mathrm{mL}$ of this solution was derivatized with $100 \mu \mathrm{L}$ BSTFA for $2 \mathrm{~h}$ at $70^{\circ} \mathrm{C}$.

\subsubsection{GC/MS analysis}

The trimethylsilylated phenolic extract was analyzed by GC/MS using an Agilent 7890A GC coupled with an Agilent $5975 \mathrm{C}$ inert mass spectrometric detector. The GC was equipped with a DB-5MS capillary column ( $30 \mathrm{~m}$ x $0.25 \mathrm{~mm}$ i.d. x $0.25 \mu \mathrm{m}$ ) obtained from Agilent (Waldbronn, Germany). Helium with a constant flow of 1.5 $\mathrm{mL} / \mathrm{min}$ was used as carrier gas. The injection volume was $1 \mu \mathrm{L}$, using a PTV injection port with the following injection temperature program: isothermal at $70{ }^{\circ} \mathrm{C}$ for $0.03 \mathrm{~min}$, at $600{ }^{\circ} \mathrm{C} / \mathrm{min}$ to $280{ }^{\circ} \mathrm{C}$, held $4 \mathrm{~min}$, at $600{ }^{\circ} \mathrm{C} / \mathrm{min}$ to $320^{\circ} \mathrm{C}$; held for $3 \mathrm{~min}$ and subsequently cooled down to $70{ }^{\circ} \mathrm{C}$. The following oven temperature program was used: isothermal at $70^{\circ} \mathrm{C}$ for $1 \mathrm{~min}$, at $25^{\circ} \mathrm{C} / \mathrm{min}$ to $120^{\circ} \mathrm{C}$, at $5{ }^{\circ} \mathrm{C} / \mathrm{min}$ to $155^{\circ} \mathrm{C}$, at $30^{\circ} \mathrm{C} / \mathrm{min}$ to $320{ }^{\circ} \mathrm{C}$ and held for $5 \mathrm{~min}$. The mass spectrometer was operated in a selected ion monitoring (SIM) mode combined with the SCAN mode with an electron impact ionization of $70 \mathrm{eV}$ using the positive ion mode. The source and the transfer line were heated up to $230{ }^{\circ} \mathrm{C}$ and $280{ }^{\circ} \mathrm{C}$, respectively. The temperature of the quadrupole was $150^{\circ} \mathrm{C}$.

\subsection{Statistical analysis}

The statistical analysis was performed by ANOVA using the software Statistica 7.1 (StatSoft Inc., 2005).

\section{Results and Discussion}

\section{$3.1 \mathrm{pH}$ and weight loss analysis}

The $\mathrm{pH}$ values and weight losses after the process of ripening are shown in Table 2 as arithmetic means and standard deviations. The $\mathrm{pH}$ values varied in a range of 4.7 to 5.3 for the smoked mini-salamis and between 5.1 and 5.9 for the non-smoked sausages. Due to the changes in the ingredients i.e. the addition of GDL as acidifier in the course of the investigations, it was not possible to correlate the $\mathrm{pH}$ values and the smoking conditions. The weight losses of the smoked mini-salamis varied between 38.3 and $48.5 \%$ and for the non-smoked mini-salamis between 37.7 and $48.5 \%$.

\subsection{Sensory evaluation}

Mini-salamis produced with intensive smoke obtained ratings closer to the expectations of the panelists concerning flavor and odor, than the lightly smoked mini-salamis. Medium smoked mini-salamis were assessed between these two classifications. Sausages smoked at a ventilator velocity of $1500 \mathrm{rpm}$ obtained ratings closer to the expectations of the panelists concerning flavor and odor than the sausages smoked at a ventilator velocity of $750 \mathrm{rpm}$. Mini-salamis smoked at $3000 \mathrm{rpm}$ were assessed between these two ventilator velocities.

\subsection{Smoke generation temperature}

The profile of the smoke generation temperature was in general described by a period of a temperature increase at the beginning of the smoking process. After this period the temperature fluctuated within a nearly constant range. For the determination of the maximal smoke generation temperature and the mean smoke generation temperature of a smoking experiment, the complete time period of the smoking process was considered.

There were differences between the first and the second smoking experiment in the temperature profile. The first smoking experiment started at room temperature and needed 12 to 20 min to reach a relatively constant level. The second smoking experiment however started at a temperature between $90{ }^{\circ} \mathrm{C}$ and $160{ }^{\circ} \mathrm{C}$ as the smoke generator was already heated up. Consequently, the time required to reach a constant temperature was shorter (5 to $15 \mathrm{~min}$ ). The mean smoke generation temperature of the second experiment was always higher than the mean smoke generation temperature of the first experiment. This tendency was not necessarily true for the smoke generation temperature maxima as, in some experiments; the maximum of smoke generation temperature of the first experiment succeeded the maximum of the second experiment for a short period of time.

The different smoke densities were produced as mentioned above. For intensive smoke the higher supply of 
smouldering air and less dilution via additive air resulted in higher smoke generation temperature maxima and mean temperatures. For medium smoke with a lower supply of smouldering air and higher dilution via additive air the smoke generation temperature maxima and mean temperatures were lower. Light smoke resulted in the lowest smoke generation temperature maxima and mean temperatures (intensive smoke: maximum temperature: $845 \pm 31^{\circ} \mathrm{C}$, mean temperature: $598 \pm 34{ }^{\circ} \mathrm{C}$; medium: maximum temperature: $680 \pm 34{ }^{\circ} \mathrm{C}$, mean temperature: $434 \pm 35{ }^{\circ} \mathrm{C}$ and light: maximum temperature: $514 \pm 80{ }^{\circ} \mathrm{C}$, mean temperature: $324 \pm 47{ }^{\circ} \mathrm{C}$ ). Previous experiments with the same smoke generator (Pöhlmann et al., 2012) showed a direct proportionality between the maximum of the smoke generation temperature and the ventilator velocity. In the present study, such dependencies could not be observed. The main differences between the previous and the present experiments were the smoking times and the temperature in the smoking chamber. In the previous study (Pöhlmann et al.), Frankfurter-type sausages were smoked at $58{ }^{\circ} \mathrm{C}$ until comparable smoking colors were obtained and therefore variable smoking times $(10-30 \mathrm{~min})$ were used. In contrast, in all experiments of the present study, the mini-salamis were smoked for $30 \mathrm{~min}$ at $22^{\circ} \mathrm{C}$.

The mean smoke generation temperature varied from $268{ }^{\circ} \mathrm{C}$ (light smoke, ventilator velocity: $1500 \mathrm{rpm}$, first experiment) to $626{ }^{\circ} \mathrm{C}$ (intensive smoke, ventilator velocity: $1500 \mathrm{rpm}$, second experiment). The smoke generation temperature maxima ranged from $417^{\circ} \mathrm{C}$ (light smoke, ventilator velocity: $750 \mathrm{rpm}$, first experiment) to $887^{\circ} \mathrm{C}$ (intensive smoke, ventilator velocity: $1500 \mathrm{rpm}$, second experiment).

The mean and the maximum of the smoke generation temperature were also influenced by the moisture of the beech wood chips. A higher moisture of the wood chips (experiment 1a, 10a and 11a: 11.7, 18.3 and 24.4\%; experiment 1b, 10b, 11b and 12b: 12.0, 19.7, 24.0 and 29.5\%) resulted in lower mean smoke generation temperatures (experiment 1a, 10a and 11a: $367-585^{\circ} \mathrm{C}, \mathrm{R}^{2}=0.96$; experiment $1 \mathrm{~b}, 10 \mathrm{~b}, 11 \mathrm{~b}$ and $12 \mathrm{~b}$ : $346-$ $\left.624{ }^{\circ} \mathrm{C}, \mathrm{R}^{2}=0.97\right)$. The mean smoke generation temperature and smoke generation temperature maximum $\left(196{ }^{\circ} \mathrm{C}\right.$ and $369{ }^{\circ} \mathrm{C}$, respectively) of experiment $12 \mathrm{a}$ with a moisture of wood chips of $29.8 \%$ showed that the wood chips did not smoulder correctly and, consequently, the results were not discussed.

\subsection{Correlations between the PAH contents, gas concentrations, and smoking conditions}

The contents of the investigated PAHs were quantified by isotope dilution analysis. Fluorinated standards were used for compounds for which ${ }^{13} \mathrm{C}$-labelled or deuterated standards were not commercially available. Under the gas chromatographic conditions described above, a separation of CHR and triphenylene (TP) was not possible (Ziegenhals et al., 2008). Consequently, a sum parameter of CHR and TP was used. TP was assessed to be not classifiable as to its carcinogenicity to humans (group 3) (IARC, 2010).

The main focus of this study was on $\mathrm{BaP}$ and PAH4 (sum content of $\mathrm{BaP}, \mathrm{BaA}, \mathrm{CHR}$ and $\mathrm{BbF}$ ). Also the contents of $\mathrm{BcL}, \mathrm{BgP}, \mathrm{BkF}, \mathrm{BjF}, \mathrm{CPP}$, and IcP were analyzed. The contents of these PAH compounds are shown in Table 3.

For experiments $1 \mathrm{a}, \mathrm{b}$ to $9 \mathrm{a}, \mathrm{b}$ the original wood chips with a moisture between 10.7 and $12.9 \%$ (mean $11.9 \pm$ $0.5 \%$ ) were used. The smoke densities influenced the smoke generation temperature whereas the ventilator velocities did not show an obvious dependency. As described above, intensive smoke resulted in the highest mean smoke generation temperatures and temperature maxima. Consequently, the PAH4 contents and the contents of the individual PAHs were higher for intensive smoke (BaP: 0.47 $\pm 0.17 ; \mathrm{PAH} 4: 3.02 \pm 0.77 \mu \mathrm{g} / \mathrm{kg} ; \mathrm{N}$ $=6$ ), than for medium (BaP: 0.25 \pm 0.07; PAH4: $2.07 \pm 0.19 \mu \mathrm{g} / \mathrm{kg} ; \mathrm{N}=6 ; p$ (intensive / medium) $<0.05$ ) and light (BaP: $0.19 \pm 0.09$; PAH4: $1.81 \pm 0.30 \mu \mathrm{g} / \mathrm{kg} ; \mathrm{N}=6 ; p$ (intensive / light) <0.01) smoke, respectively (Figure 1) The same tendency was observed between medium and light smoke, but could not be proofed statistically $(p>$ 0.05). The different ventilator velocities did not influence the contents of $\mathrm{BaP}$ and $\mathrm{PAH} 4$. The mean $\mathrm{BaP}$ and PAH4 contents for the ventilator velocities 750,1500 , and $3000 \mathrm{rpm}$ were very similar to each other ( $3000 \mathrm{rpm}$ : BaP: $0.31 \pm 0.07 \mu \mathrm{g} / \mathrm{kg}$, PAH4: $2.25 \pm 0.19 \mu \mathrm{g} / \mathrm{kg} ; 1500 \mathrm{rpm}$ : BaP: $0.28 \pm 0.20 \mu \mathrm{g} / \mathrm{kg}$, PAH4: $2.27 \pm 0.86 \mu \mathrm{g} / \mathrm{kg}$; $750 \mathrm{rpm}$ : BaP: $0.31 \pm 0.22 \mu \mathrm{g} / \mathrm{kg}$, PAH4: $2.37 \pm 0.95 \mu \mathrm{g} / \mathrm{kg} ; \mathrm{N}=6$ ). Yet the percentage standard deviations of $\mathrm{BaP}$ and PAH4 contents were significantly lower for a ventilator velocity of $3000 \mathrm{rpm}$ (BaP: 24\%, PAH4: 8\%) than for 1500 (BaP: 70\%, PAH4: 38\%) and $750 \mathrm{rpm}$ (BaP: 69\%, PAH4: 40\%) (Figure 2). Non-smoked mini-salamis were also analysed (BaP: $0.09 \pm 0.06$; PAH4: $1.39 \pm 0.27 \mu \mathrm{g} / \mathrm{kg} ; \mathrm{N}=13$ ). A differentiation between the first and the second smoking experiment showed that the mean smoke generation temperatures of the first experiment were always lower than those of the second experiment. Yet the contents of PAH4 and the other analyzed PAHs were higher in the first experiment than in the second one. Consequently, the higher PAH contents detected in the first smoking experiment compared to the second experiment could not be explained by higher smoke generation temperatures. It should be noted that the concentrations of carbon monoxide (CO) in the smoking chamber showed the same tendency as the PAH contents: For experiments $1 \mathrm{a}, \mathrm{b}$ to $7 \mathrm{a}, \mathrm{b}$ the $\mathrm{CO}$ 
maximum concentrations of the first smoking experiment were on average about $6 \%$ higher (first experiment: $2547-10953 \mathrm{ppm}$ ) than the CO maximum concentrations of the second experiment (2396-10320 ppm) (Figure 3 ). For the experiments $8 \mathrm{a}, \mathrm{b}$ and $9 \mathrm{a}, \mathrm{b}$, the $\mathrm{CO}$ maximum concentrations of the first and the second experiment were very similar to each other ( 8 a: 2915 ppm, 8 b: 2925 ppm; 9 a: 3339 ppm, 9b: 3352 ppm), and the PAH4 contents ( 8 a: $1.91 \mu \mathrm{g} / \mathrm{kg}, 8 \mathrm{~b}: 1.60 \mu \mathrm{g} / \mathrm{kg} ; 9 \mathrm{a}: 1.56 \mu \mathrm{g} / \mathrm{kg}, 9 \mathrm{~b}: 1.48 \mu \mathrm{g} / \mathrm{kg}$ ) were not much higher than those of the non-smoked salamis $(1.39 \pm 0.27 \mu \mathrm{g} / \mathrm{kg})$. The higher $\mathrm{CO}$ maximum concentrations of the first experiments 1 a to 7 a indicate a less complete combustion of the wood chips compared to the second experiment. The conditions of a less complete combustion possibly favor the formation of the PAHs. The ratios between the maxima of $\mathrm{CO}$ and carbon dioxide $\left(\mathrm{CO}_{2}\right)$ concentrations were on average 0.8 for intensive, 0.7 for medium, and 0.5 for light smoke. There were no differences in these ratios between the first and the second smoking experiment, but the mean smoke generation temperature in the second experiment was on average $54{ }^{\circ} \mathrm{C}$ higher for intensive smoke, $48{ }^{\circ} \mathrm{C}$ higher for medium smoke, and $83{ }^{\circ} \mathrm{C}$ higher for light smoke. The minimum concentrations of oxygen $\left(\mathrm{O}_{2}\right)(19.2-20.6 \%)$ did not show any differences between the first and the second smoking experiments. As mentioned in section 3.3, the temperature profiles of the first and the second smoking experiment were different. The first experiment resulted in higher PAH contents, but the mean smoke generation temperatures were lower. On the other hand, in the first smoking experiments a longer time period was needed to reach a constant temperature level than in the second experiments.

The influence of the moisture of the wood chips was also investigated applying a constant smoke density (intensive smoke) and ventilator velocity (3000 rpm). As described above, the higher moisture of the wood chips resulted in lower mean smoke generation temperatures. But a higher moisture of the wood chips also resulted in higher PAH4 contents in a linear relationship (experiment 1a, 10a and 11a: BaP $0.41-0.53 \mu \mathrm{g} / \mathrm{kg}\left(\mathrm{R}^{2}=0.99\right)$, PAH4 $2.60-3.26 \mu \mathrm{g} / \mathrm{kg}\left(\mathrm{R}^{2}=0.99\right)$; experiment $1 \mathrm{~b}, 10 \mathrm{~b}$ and $11 \mathrm{~b}$ : BaP $0.32-0.47 \mu \mathrm{g} / \mathrm{kg}\left(\mathrm{R}^{2}=0.98\right)$, PAH4 2.30 $-3.09 \mu \mathrm{g} / \mathrm{kg}\left(\mathrm{R}^{2}=0.98\right)$ ) (Figure 4). The temperature data of experiment 12a with a moisture of the wood chips of $29.8 \%$ showed that these wood chips did not smoulder properly. Consequently, the PAH4 content of this experiment did not fit in the linear correlation and was not discussed any further. However, the PAH4 content of smoking experiment $12 \mathrm{~b}$ (moisture of wood chips $29.5 \%$ ), with a common temperature profile showed also a lower PAH4 content than expected and was not included in the calculation of the correlation. Consequently, the moisture of the wood chips of $30 \%$ caused such a low smoke generation temperature that the other effects, which had usually led to higher PAH4 contents, were compensated.

In a previous study it was shown that the percentage contributions of $\mathrm{BaA}, \mathrm{BbF}, \mathrm{CHR}+\mathrm{TP}$, and $\mathrm{BaP}$ to $\mathrm{PAH} 4$ were not constant (Pöhlmann et al., 2012). An increasing absolute content of PAH4 resulted in higher percentage contributions of $\mathrm{BaP}$ and $\mathrm{BbF}$ and lower contributions of $\mathrm{BaA}$ and $\mathrm{CHR}+\mathrm{TP}$. In this study, the same tendencies were observed. The percentage contribution of BaA decreased from 48 to $29 \%$ and for CHR+TP from 43 to $31 \%$. The percentage contribution of $\mathrm{BbF}$ increased from 5 to $17 \%$ and for $\mathrm{BaP}$ from 6 to $18 \%$ (Figure 5). The formation of PAHs with a higher molecular weight like $\mathrm{BbF}$ and $\mathrm{BaP}$ are favored under higher temperatures, which is also a condition that causes higher absolute PAH4 contents (Mücke et al., 1991; Pöhlmann et al. 2012).

\subsection{Correlations between the contents of phenolic substances and the smoking conditions}

The contents of the phenolic compounds in the cold smoked sausages are shown in Table 4 . The samples were all analyzed in duplicate. The relative standard deviation of the analyzed samples was below $20 \%$, and the recovery in spiked matrix ranged from $72 \%$ to $84 \%$. The quantification was performed by a response factor calibration. All the compounds were quantified using ${ }^{13} \mathrm{C}_{6}$-guaiacol as internal standard and guaiacol- $\mathrm{d}_{4}$ as recovery standard.

The highest sum content of the five phenolic compounds $(76.2 \mathrm{mg} / \mathrm{kg})$ was detected in intensively smoked sausages applying a ventilator velocity of $750 \mathrm{rpm}$. The lowest contents with an identical moisture level of the wood chips (11.9\%) were detected in lightly smoked sausages $(29.6 \mathrm{mg} / \mathrm{kg}$; ventilator velocity: $3000 \mathrm{rpm})$.

The mean content of eugenol in smoked mini-salamis was only $2.2 \mathrm{mg} / \mathrm{kg}$. The eugenol content in non-smoked salamis was half that $(1.1 \mathrm{mg} / \mathrm{kg})$. Furthermore, the content of trans-isoeugenol was about three times higher than the content in non-smoked sausages. Consequently, for the interpretation of the contents of the individual phenolic compounds, the contents of eugenol and trans-isoeugenol were not considered. The contents of guaiacol, 4-methylguaiacol, and syringol in non-smoked sausages were about ten times lower than the contents in smoked sausages.

Guaiacol was the main compound of the five analyzed phenolic compounds showing contents between 8.8 $\mathrm{mg} / \mathrm{kg}$ (light smoke; $3000 \mathrm{rpm}$ ) and $24.5 \mathrm{mg} / \mathrm{kg}$ (intensive smoke; $750 \mathrm{rpm}$ ). The contents of syringol ranged between $8.9 \mathrm{mg} / \mathrm{kg}$ (light smoke; $3000 \mathrm{rpm}$ ) and $20.3 \mathrm{mg} / \mathrm{kg}$ (intensive smoke; $750 \mathrm{rpm}$ ), and the contents of 
4-methylguaiacol were measured between $6.5 \mathrm{mg} / \mathrm{kg}$ (light smoke; $3000 \mathrm{rpm}$ ) and $20.3 \mathrm{mg} / \mathrm{kg}$ (light smoke; $1500 \mathrm{rpm})$.

The correlation between the smoke density, the ventilator velocity, and the sum content of the five phenolic compounds is shown in Figure 6. The mean value of the two smoking experiments was used for the interpretation.

The ventilator velocity influenced the content of phenolic compounds in intensively smoked mini- salamis. The sum content of the five phenolic compounds increased from $45.8 \mathrm{mg} / \mathrm{kg}$ at a ventilator velocity of $3000 \mathrm{rpm}$ to $74.6 \mathrm{mg} / \mathrm{kg}$ at a ventilator velocity of $750 \mathrm{rpm}$. The content of medium smoked sausages showed no dependency on different ventilator velocities. The highest sum content of phenolic compounds in lightly smoked sausages was analyzed in mini-salamis smoked at a ventilator velocity of $1500 \mathrm{rpm}(60.9 \mathrm{mg} / \mathrm{kg})$. The lowest content was detected in lightly smoked sausages applying a ventilator velocity of $3000 \mathrm{rpm}(35.3 \mathrm{mg} / \mathrm{kg})$.

The smoke density showed a great influence on the maximum of the smoke generation temperature. The phenolic content of mini-salamis smoked at a ventilator velocity of $3000 \mathrm{rpm}$ and $1500 \mathrm{rpm}$ showed no direct correlation to the smoke density. At $3000 \mathrm{rpm}$ sum contents of the five phenolic compounds between $35.3 \mathrm{mg} / \mathrm{kg}$ (light smoke) and $52.6 \mathrm{mg} / \mathrm{kg}$ (medium smoke) were detected, at $1500 \mathrm{rpm}$ the sum content ranged between 53.5 $\mathrm{mg} / \mathrm{kg}$ (medium smoke) and $67.8 \mathrm{mg} / \mathrm{kg}$ (intensive smoke). In contrast, the sum content of phenolic compounds in mini-salamis smoked at $750 \mathrm{rpm}$ decreased from $74.6 \mathrm{mg} / \mathrm{kg}$ (intensive smoke) to $59.5 \mathrm{mg} / \mathrm{kg}$ (medium smoke) and up to $50.6 \mathrm{mg} / \mathrm{kg}$ (light smoke).

As already mentioned, the moisture of the wood chips influenced the maximum of the smoke generation temperature. The contents of phenolic compounds in the mini-salamis that were smoked with moistened wood chips also showed a dependency on the different moisture of the wood chips. The sum content of the phenolic compounds increased from $41.2 \mathrm{mg} / \mathrm{kg}$ (original wood moisture: 11.7\%; maximum of smoke generation temperature: $827{ }^{\circ} \mathrm{C}$ ) to $68.2 \mathrm{mg} / \mathrm{kg}$ (wood moisture: $29.5 \%$; maximum of smoke generation temperature: $\left.544^{\circ} \mathrm{C}\right)$.

A correlation between the sum content of the five phenolic compounds and the content of the PAH4 was only observable for the experiments using wood chips that had a different moisture. The PAH4 contents of the smoked mini-salamis with the highest phenolic contents were analyzed at about $3.1 \mu \mathrm{g} / \mathrm{kg}$. Therefore, the desired objective of lowering the PAH contents without lowering the contents of the phenolic compounds was not achieved by moistening of wood chips.

\section{Conclusions}

Mini-salamis with low PAH contents were produced in all of the smoking experiments. The contents of BaP were in the range of 0.1 to $0.7 \mu \mathrm{g} / \mathrm{kg}$ (mean: $0.3 \mu \mathrm{g} / \mathrm{kg}$ ), and the contents of PAH4 were between 1.5 and 4.1 $\mu \mathrm{g} / \mathrm{kg}$ (mean: $2.5 \mu \mathrm{g} / \mathrm{kg}$ ). Therefore the mean contents of BaP and PAH4 are more than a factor of 10 below the maximum levels established by the EU legislation. A minimization of the PAH compounds in cold smoked sausages using smouldering smoke is possible. The most important parameter influencing the PAH contents is the smoke generation temperature which is influenced by the smoke density. Therefore, an accurate control of the smoke generation temperature to avoid the maxima of smoke generation temperature above $800{ }^{\circ} \mathrm{C}(p<0.05)$ and to achieve mean smoke generation temperatures below $500{ }^{\circ} \mathrm{C}(p<0.05)$ is a promising approach for lowering the PAH contents in cold smoked sausages.

The minimization of these low PAH contents in cold smoked mini-salamis is limited as the lowest observed PAH contents in smoked sausages were nearly at the same level as in unsmoked sausages. The reason for this contamination, which cannot be attributed to PAH-containing spices, is probably a contamination by the air in which PAHs occur ubiquitously in the climatic chamber since the samples are stored in the chamber for about four days. This kind of contamination cannot be excluded with justifiable efforts, consequently, the PAH contents at this low level are a limitation to the minimization strategies for PAHs in cold smoked raw sausages.

As it was observed for hot smoked sausages (Pöhlmann et al., 2012), an increase in the moisture content of the wood chips also does not seem to be a reasonable approach for reducing the PAH contents in cold smoked sausages using smouldering smoke. This proved to be counterproductive as even smoking with wood chips of a higher moisture content led to higher PAH contents.

For PAH minimization strategies it does not seem to be necessary to consider the contents of phenolic compounds since sufficient amounts of phenolic compounds (sum contents above $30 \mathrm{mg} / \mathrm{kg}$ ) were detectable in all of the smoking experiments.

The risk of the formation of PAH compounds during the cold smoking process of meat products is higher for the 
first smoking experiment when starting the smoking process with a cold smoke generator as in the smoking experiments performed in this study, slightly, but not significantly $(p>0.05)$ lower PAH contents were detected in the second experiment.

\section{Acknowledgements}

The authors would like to thank Gertrud Eigner, Elisabeth Klötzer, and Lisa Schwitz for their excellent technical assistance, Bertram Schregle for producing the sausages and performing the smoking experiments, and Fessmann $\mathrm{GmbH}$ und Co KG (Winnenden, Germany) for providing the smoking chamber.

\section{References}

Antonacopoulos, N. (1960). Verbesserte Apparatur zur quantitativen Destillation wasserdampfflüchtiger Stoffe. Zeitschrift für Lebensmittel-Untersuchung und -Forschung, 13, 113-160. http://dx.doi.org/10.1007/BF01858931

Bratzler, L. J., Spooner, M. E., Weatherspoon, J. B., \& Maxey, J. A. (1969). Smoke Flavor as Related to Phenol, Carbonyl and Acid Content of Bologna. Journal of Food Science, 34, 146-148. http://dx.doi.org/10.1111/j.1365-2621.1969.tb00906.x

CAC. (2008), Codex Alimentarius Commission. Proposed Draft Code of Practice for the Reduction of Contamination of Food with Polycyclic Aromatic Hydrocarbons (PAH) from Smoking and Direct Drying Processes: ftp://ftp.fao.org/codex/alinorm08/al31_41e.pdf.

Commission Regulation (EU) No 835/2011 of 19 August 2011 amending Regulation (EC) No 1881/2006 as regards maximum levels for polycyclic aromatic hydrocarbons in foodstuffs. Official Journal of the European Union L, 215, 4-8

Davidson, P. M. \& Branden, A. L. (1981). Anti-microbial activity of non-halogenated phenolic-compounds. Journal of Food Protection, 44, 623-632.

Djinovic, J., Popovic, A., \& Jira, W. (2008a). Polycyclic aromatic hydrocarbons (PAHs) in different types of smoked meat products from Serbia. Meat Science, 80, 449-456. http://dx.doi.org/10.1016/j.meatsci.2008.01.008

Djinovic, J., Popovic, A., \& Jira, W. (2008b). Polycyclic aromatic hydrocarbons (PAHs) in traditional and industrial smoked beef and pork ham from Serbia. European Food Research \& Technology, 227, 1191-1198. http://dx.doi.org/10.1007/s00217-008-0836-8

EFSA. (2008). Scientific Opinion of the Panel on Contaminants in the Food Chain on a request from the European Commission on Polycyclic Aromatic Hydrocarbons in Food. EFSA Journal, 724, 1-114

IARC. (1987). Monographs on the Evaluation of the Carcinogenic Risk of Chemicals to Humans. Overall Evaluation of Carcinogenity: An Updating of IARC Monographs, Supplement 7, International Agency for Research on Cancer, Lyon, France.

IARC. (2010). Monographs on the Evaluation of Carcinogenic Risks to Humans. International Agency for Research on Cancer, Lyon, France. http://monographs.iarc.fr/ENG/Monographs/vo192/mono92.pdf.

Jira, W. (2004). A GC/MS method for the determination of carcinogenic polycyclic aromatic hydrocarbons (PAH) in smoked meat products and liquid smokes. European Food Research \& Technology, 218, 208-212. http://dx.doi.org/10.1007/s00217-003-0827-8

Jira, W., Ziegenhals, K., \& Speer, K. (2008). Gas chromatography-mass spectrometry (GC-MS) method for the determination of 16 European priority polycyclic aromatic hydrocarbons in smoked meat products and edible oils. Food Additives \& Contaminants: Part A, 25 (6), 704-713. http://dx.doi.org/10.1080/02652030701697769

Kjallstrand, J., \& Petersson, G. (2001). Phenolic antioxidants in wood smoke. Science of the Total Environment, 277, 69-75. http://dx.doi.org/10.1016/S0048-9697(00)00863-9

Mücke, W., Steinmetzer, H. C., Stumpp, J., Baumeister, W., Boneberg, R., \& Vierle, O. (1991). PAK-Immisionskonzentrationen - Ergebnisse mehrjähriger Messungen polycyclischer aromatischer Kohlenwasserstoffe in Bayern. Umweltwissenschaften und Schadstoff-Forschung - Zeitschrift für Umweltchemie und Ökotoxikologie, 3, 176-179.

Pöhlmann, M., Hitzel, A., Schwägele, F., Speer, K., \& Jira, W. (2012). Contents of polycyclic aromatic hydrocarbons (PAH) and phenolic substances in Frankfurter-type sausages depending on smoking conditions using glow smoke. Meat Science, 90, 176-184. http://dx.doi.org/10.1016/j.meatsci.2011.06.024

Sander, L. C., \& Wise, S. A. (1997). Polycyclic Aromatic Hydrocarbon Structure Index. NIST Special Publication 922 (revised 2011), Gaithersburg: National Institute of Standards and Technology. 
http://www.nist.gov/mml/analytical/organic/sp922page.cfm.

SCF, Scientific Committee on Food. (2002). Opinion of the Scientific Committee on Food on the Risks to Human Health of Polycyclic Aromatic Hydrocarbons in Food. http://ec.europa.eu/food/food/chemicalsafety/contaminants/out153_en.pdf

Smith, I. M. (1984). PAH from coal utilization. Emissions and effects, Report No ICTIS/TR29, IEA Coal Research London.

Toth, L. (1982). Chemie der Räucherung. Weinheim, Germany.

Wittkowski, R. (1985). Phenole im Räucherrauch. VCH Verlagsgesellschaft Weinheim.

Ziegenhals, K., Hübschmann, H. J., Speer, K., \& Jira, W. (2008). Fast-GC/HRMS to quantify the EU priority PAH. Journal of Separation Science, 31, 1779-1786. http://dx.doi.org/10.1002/jswsc.200700641

Table 1. Different process parameters for the smoking experiments

\begin{tabular}{ccccc}
\hline Experiment & $\begin{array}{c}\text { Smoking time } \\
{[\mathrm{min}]}\end{array}$ & Smoke density & $\begin{array}{c}\text { Ventilator velocity } \\
{[\mathrm{rpm}]}\end{array}$ & $\begin{array}{c}\text { Moisture of beech } \\
\text { wood [\%] }\end{array}$ \\
\hline $1 \mathrm{a}$ & 30 & intensive & 3000 & 11.7 \\
$1 \mathrm{~b}$ & $27^{*}$ & intensive & 3000 & 12.0 \\
$2 \mathrm{a}$ & 30 & intensive & 1500 & 11.7 \\
$2 \mathrm{~b}$ & 30 & intensive & 1500 & 12.9 \\
$3 \mathrm{a}$ & 30 & intensive & 750 & 12.0 \\
$3 \mathrm{~b}$ & 30 & intensive & 750 & 11.9 \\
$4 \mathrm{a}$ & 30 & medium & 3000 & 10.7 \\
$4 \mathrm{~b}$ & 30 & medium & 3000 & 11.5 \\
$5 \mathrm{a}$ & 30 & medium & 1500 & 11.7 \\
$5 \mathrm{~b}$ & 30 & medium & 1500 & 11.6 \\
$6 \mathrm{a}$ & 30 & medium & 750 & 12.2 \\
$6 \mathrm{~b}$ & 30 & medium & 750 & 12.6 \\
$7 \mathrm{a}$ & 30 & light & 3000 & 11.9 \\
$7 \mathrm{~b}$ & 30 & light & 3000 & 12.0 \\
$8 \mathrm{a}$ & 30 & light & 1500 & 12.1 \\
$8 \mathrm{~b}$ & 30 & light & 1500 & 12.2 \\
$9 \mathrm{a}$ & 30 & light & 750 & 11.5 \\
$9 \mathrm{~b}$ & 30 & light & 750 & 12.2 \\
$10 \mathrm{a}$ & 30 & intensive & 3000 & 18.3 \\
$10 \mathrm{~b}$ & 30 & intensive & 3000 & 19.7 \\
$11 \mathrm{a}$ & 30 & intensive & 3000 & 24.4 \\
$11 \mathrm{~b}$ & 30 & intensive & 3000 & 24.0 \\
$12 \mathrm{a}$ & intensive & 3000 & 29.8 \\
$12 \mathrm{~b}$ & intensive & 3000 & 29.5 \\
\hline
\end{tabular}

* Smoking experiment $1 \mathrm{~b}$ was interrupted after $27 \mathrm{~min}$

- For the interpretation of experiment 12 the results from experiment $12 \mathrm{~b}$ were used, because the smoking experiment 12 a failed (the maximum of smoke generation temperature was only $370^{\circ} \mathrm{C}$ ). 
Table 2. Results of $\mathrm{pH}$ value and weight loss (arithmetic mean and standard deviation)

\begin{tabular}{lccccc}
\hline & $\begin{array}{c}\text { smoked mini } \\
\text { salamis }\end{array}$ & Light smoke & Medium smoke & Intensive smoke & $\begin{array}{c}\text { Non-smoked mini } \\
\text { salamis }\end{array}$ \\
\hline pH value & $5.1 \pm 0.2$ & $5.1 \pm 0.1$ & $5.2 \pm 0.2$ & $5.0 \pm 0.2$ & $5.5 \pm 0.3$ \\
$\begin{array}{l}\text { Weight } \\
\text { loss [\%] }\end{array}$ & $43.9 \pm 3.6$ & $43.1 \pm 4.1$ & $45.2 \pm 3.5$ & $43.6 \pm 3.6$ & $44.1 \pm 3.6$ \\
\hline
\end{tabular}

Table 3. PAH contents $[\mu \mathrm{g} / \mathrm{kg}]$ in smoked mini salamis applying different smoking conditions

\begin{tabular}{|c|c|c|c|c|c|c|c|c|c|c|c|c|}
\hline Experiment & $\begin{array}{l}\mathrm{BaA} \\
{[\mu \mathrm{g} / \mathrm{kg}} \\
]\end{array}$ & $\begin{array}{l}\mathrm{CHR} \\
+\mathrm{TP} \\
{[\mu \mathrm{g} / \mathrm{kg}}\end{array}$ & $\begin{array}{l}\mathrm{BbF} \\
{[\mu \mathrm{g} / \mathrm{kg}} \\
]\end{array}$ & $\begin{array}{l}\mathrm{BaP} \\
{[\mu \mathrm{g} / \mathrm{kg}} \\
]\end{array}$ & $\begin{array}{l}\mathrm{BcL} \\
{[\mu \mathrm{g} / \mathrm{kg}} \\
]\end{array}$ & $\begin{array}{l}\text { CPP } \\
{[\mu \mathrm{g} / \mathrm{kg}} \\
]\end{array}$ & $\begin{array}{l}\mathrm{BjF} \\
{[\mu \mathrm{g} / \mathrm{kg}} \\
]\end{array}$ & $\begin{array}{l}\mathrm{BkF} \\
{[\mu \mathrm{g} / \mathrm{kg}} \\
]\end{array}$ & $\begin{array}{l}\text { IcP } \\
{[\mu \mathrm{g} / \mathrm{kg}} \\
]\end{array}$ & $\begin{array}{l}\mathrm{BgP} \\
{[\mu \mathrm{g} / \mathrm{kg}} \\
]\end{array}$ & $\begin{array}{l}\text { PAH4 } \\
{[\mu \mathrm{g} / \mathrm{kg}} \\
]\end{array}$ & $\begin{array}{l}\text { Total } \\
{[\mu \mathrm{g} / \mathrm{kg}} \\
]\end{array}$ \\
\hline $1 \mathrm{a}$ & 0.94 & 0.91 & 0.34 & 0.41 & 1.86 & 0.64 & 0.23 & 0.18 & 0.23 & 0.42 & 2.60 & 6.16 \\
\hline $1 b^{*}$ & 0.89 & 0.87 & 0.21 & 0.32 & 1.61 & 0.41 & 0.21 & 0.15 & 0.17 & 0.23 & 2.30 & 5.07 \\
\hline $2 \mathrm{a}$ & 1.57 & 1.34 & 0.35 & 0.65 & 3.24 & 1.02 & 0.38 & 0.25 & 0.35 & 0.37 & 3.91 & 9.52 \\
\hline $2 b$ & 1.05 & 0.92 & 0.22 & 0.30 & 2.59 & 0.54 & 0.17 & 0.13 & 0.16 & 0.16 & 2.49 & 6.23 \\
\hline $3 a$ & 1.58 & 1.26 & 0.51 & 0.71 & 3.19 & 1.24 & 0.35 & 0.26 & 0.37 & 0.32 & 4.06 & 9.78 \\
\hline $3 \mathrm{~b}$ & 1.15 & 0.95 & 0.24 & 0.40 & 2.66 & 0.59 & 0.19 & 0.13 & 0.19 & 0.19 & 2.74 & 6.69 \\
\hline $4 \mathrm{a}$ & 0.64 & 0.87 & 0.37 & 0.35 & 0.85 & 0.30 & 0.22 & 0.20 & 0.25 & 0.45 & 2.23 & 4.49 \\
\hline $4 b$ & 0.94 & 0.81 & 0.17 & 0.19 & 2.55 & 0.56 & 0.12 & 0.08 & 0.11 & 0.21 & 2.10 & 5.73 \\
\hline $5 \mathrm{a}$ & 0.75 & 0.72 & 0.20 & 0.28 & 1.78 & 0.31 & 0.13 & 0.11 & 0.15 & 0.23 & 1.94 & 4.66 \\
\hline $5 \mathrm{~b}$ & 0.77 & 0.68 & 0.14 & 0.17 & 1.99 & 0.29 & 0.09 & 0.06 & 0.11 & 0.21 & 1.76 & 4.50 \\
\hline $6 a$ & 0.88 & 0.82 & 0.18 & 0.25 & 2.47 & 0.55 & 0.13 & 0.11 & 0.14 & 0.19 & 2.12 & 5.71 \\
\hline $6 \mathrm{~b}$ & 0.97 & 0.92 & 0.15 & 0.23 & 2.35 & 0.33 & 0.14 & 0.12 & 0.16 & 0.33 & 2.28 & 5.71 \\
\hline $7 a$ & 0.87 & 0.90 & 0.10 & 0.31 & 1.27 & 0.30 & 0.20 & 0.20 & 0.21 & 0.26 & 2.18 & 4.61 \\
\hline $7 \mathrm{~b}$ & 0.79 & 0.90 & 0.14 & 0.28 & 1.21 & 0.22 & 0.20 & 0.21 & 0.22 & 0.31 & 2.10 & 4.48 \\
\hline $8 \mathrm{a}$ & 0.84 & 0.75 & 0.15 & 0.17 & 2.07 & 0.43 & 0.10 & 0.09 & 0.11 & 0.21 & 1.91 & 4.91 \\
\hline $8 \mathrm{~b}$ & 0.76 & 0.63 & 0.11 & 0.10 & 2.15 & 0.34 & 0.06 & 0.05 & 0.05 & 0.11 & 1.60 & 4.36 \\
\hline $9 \mathrm{a}$ & 0.67 & 0.64 & 0.11 & 0.13 & 1.47 & 0.32 & 0.08 & 0.07 & 0.07 & 0.10 & 1.56 & 3.67 \\
\hline $9 \mathrm{~b}$ & 0.61 & 0.60 & 0.12 & 0.15 & 1.14 & 0.16 & 0.09 & 0.08 & 0.08 & 0.16 & 1.48 & 3.20 \\
\hline $10 \mathrm{a}$ & 1.19 & 0.99 & 0.35 & 0.47 & 2.34 & 0.89 & 0.24 & 0.18 & 0.26 & 0.41 & 2.99 & 7.31 \\
\hline $10 \mathrm{~b}$ & 1.18 & 1.01 & 0.31 & 0.40 & 2.24 & 0.72 & 0.21 & 0.16 & 0.20 & 0.33 & 2.90 & 6.76 \\
\hline $11 \mathrm{a}$ & 1.25 & 1.10 & 0.38 & 0.53 & 2.00 & 0.88 & 0.26 & 0.20 & 0.26 & 0.25 & 3.26 & 7.10 \\
\hline $11 \mathrm{~b}$ & 1.15 & 1.03 & 0.44 & 0.47 & 1.91 & 0.65 & 0.25 & 0.20 & 0.23 & 0.31 & 3.09 & 6.65 \\
\hline $12 \mathrm{a}^{\circ}$ & 1.04 & 1.34 & 0.20 & 0.26 & 2.02 & 0.77 & 0.18 & 0.13 & 0.14 & 0.12 & 2.83 & 6.19 \\
\hline $12 \mathrm{~b}$ & 1.34 & 1.13 & 0.17 & 0.34 & 2.56 & 0.92 & 0.19 & 0.14 & 0.17 & 0.13 & 2.98 & 7.08 \\
\hline $\begin{array}{l}\text { smoked } \\
(\mathrm{N}=23)\end{array}$ & $\begin{array}{l}0.99 \pm \\
0.27\end{array}$ & $\begin{array}{l}0.90 \pm \\
0.19\end{array}$ & $\begin{array}{l}0.24 \pm \\
0.12 \\
\end{array}$ & $\begin{array}{l}0.33 \pm \\
0.16\end{array}$ & $\begin{array}{l}2.07 \pm \\
0.62\end{array}$ & $\begin{array}{l}0.55 \pm \\
0.29\end{array}$ & $\begin{array}{l}0.18 \pm \\
0.08\end{array}$ & $\begin{array}{l}0.15 \pm \\
0.06\end{array}$ & $\begin{array}{l}0.18 \pm \\
0.08\end{array}$ & $\begin{array}{l}0.26 \pm \\
0.10\end{array}$ & $\begin{array}{l}2.46 \pm \\
0.70\end{array}$ & $\begin{array}{l}5.85 \pm \\
1.66\end{array}$ \\
\hline $\begin{array}{l}\text { non-smoked } \\
(\mathrm{N}=13)\end{array}$ & $\begin{array}{l}0.60 \pm \\
0.12\end{array}$ & $\begin{array}{l}0.60 \pm \\
0.12\end{array}$ & $\begin{array}{l}0.10 \pm \\
0.04\end{array}$ & $\begin{array}{l}0.09 \pm \\
0.06\end{array}$ & $\begin{array}{l}1.63 \pm \\
0.41\end{array}$ & $\begin{array}{l}0.31 \pm \\
0.12\end{array}$ & $\begin{array}{l}0.07 \pm \\
0.03\end{array}$ & $\begin{array}{l}0.05 \pm \\
0.03\end{array}$ & $\begin{array}{l}0.07 \pm \\
0.05\end{array}$ & $\begin{array}{l}0.12 \pm \\
0.06\end{array}$ & $\begin{array}{l}1.39 \pm \\
0.27\end{array}$ & $\begin{array}{l}3.64 \pm \\
0.68\end{array}$ \\
\hline $\begin{array}{l}\text { p-value(smoked/ } \\
\text { non-smoked) }\end{array}$ & $\begin{array}{l}< \\
0.001\end{array}$ & $\begin{array}{l}< \\
0.001\end{array}$ & $\begin{array}{l}< \\
0.001\end{array}$ & $\begin{array}{l}< \\
<0.001\end{array}$ & $<0.05$ & $<0.01$ & $\begin{array}{l}< \\
0.001\end{array}$ & $\begin{array}{l}< \\
0.001\end{array}$ & $\begin{array}{l}< \\
<0.001\end{array}$ & $\begin{array}{l}< \\
0.001\end{array}$ & $\begin{array}{l}< \\
<0.001\end{array}$ & $\begin{array}{l}< \\
0.001\end{array}$ \\
\hline
\end{tabular}

* Smoking experiment $1 \mathrm{~b}$ was interrupted; the smoking time was only $27 \mathrm{~min}$

- For the interpretation of experiment 12 the results from experiment $12 \mathrm{~b}$ were used, because the smoking experiment 12 a failed (the maximum of smoke generation temperature was only $370^{\circ} \mathrm{C}$ ). 
Table 4. Contents of phenolic substances $[\mathrm{mg} / \mathrm{kg}]$ in smoked mini-salamis applying different smoking conditions

\begin{tabular}{|c|c|c|c|c|c|c|}
\hline Experiment & $\begin{array}{l}\text { Guaiacol } \\
{[\mathrm{mg} / \mathrm{kg}]}\end{array}$ & $\begin{array}{c}\text { 4-Methylguaiacol } \\
{[\mathrm{mg} / \mathrm{kg}]}\end{array}$ & $\begin{array}{l}\text { Syringol } \\
{[\mathrm{mg} / \mathrm{kg}]}\end{array}$ & $\begin{array}{l}\text { Eugenol } \\
{[\mathrm{mg} / \mathrm{kg}]}\end{array}$ & $\begin{array}{c}\text { Trans-isoeugenol } \\
{[\mathrm{mg} / \mathrm{kg}]}\end{array}$ & $\begin{array}{c}\text { Sum of } 5 \text { phenols } \\
{[\mathrm{mg} / \mathrm{kg}]}\end{array}$ \\
\hline $1 \mathrm{a}$ & 14.9 & 9.4 & 10.2 & 1.7 & 4.9 & 41.2 \\
\hline $1 b^{*}$ & 16.7 & 12.3 & 13.9 & 1.8 & 5.7 & 50.4 \\
\hline $2 \mathrm{a}$ & 22.2 & 17.1 & 16.2 & 2.8 & 10.1 & 68.4 \\
\hline $2 b$ & 22.9 & 17.9 & 16.8 & 2.6 & 7.0 & 67.2 \\
\hline $3 \mathrm{a}$ & 22.9 & 17.7 & 20.3 & 3.1 & 9.0 & 73.0 \\
\hline $3 \mathrm{~b}$ & 24.5 & 19.1 & 19.1 & 2.9 & 10.6 & 76.2 \\
\hline $4 \mathrm{a}$ & 15.3 & 9.6 & 12.8 & 1.6 & 5.4 & 44.8 \\
\hline $4 \mathrm{~b}$ & 17.7 & 15.5 & 16.2 & 2.6 & 8.4 & 60.4 \\
\hline $5 \mathrm{a}$ & 14.8 & 12.2 & 11.1 & 1.9 & 6.0 & 46.0 \\
\hline $5 \mathrm{~b}$ & 19.1 & 16.1 & 14.7 & 2.4 & 8.5 & 60.9 \\
\hline $6 \mathrm{a}$ & 16.8 & 14.0 & 14.9 & 2.2 & 7.9 & 55.9 \\
\hline $6 \mathrm{~b}$ & 19.1 & 15.8 & 17.0 & 2.5 & 8.7 & 63.0 \\
\hline $7 \mathrm{a}$ & 8.8 & 6.5 & 8.9 & 1.4 & 4.1 & 29.6 \\
\hline $7 \mathrm{~b}$ & 11.6 & 9.8 & 12.6 & 1.9 & 5.2 & 41.0 \\
\hline $8 \mathrm{a}$ & 14.5 & 12.6 & 12.7 & 2.0 & 6.4 & 48.2 \\
\hline $8 \mathrm{~b}$ & 22.3 & 20.3 & 19.0 & 2.9 & 9.2 & 73.6 \\
\hline 9 a & 14.4 & 12.0 & 10.9 & 1.9 & 6.7 & 45.8 \\
\hline $9 \mathrm{~b}$ & 17.3 & 14.9 & 14.6 & 2.3 & 6.2 & 55.3 \\
\hline $10 \mathrm{a}$ & 15.8 & 11.5 & 11.7 & 2.3 & 7.2 & 48.6 \\
\hline $10 \mathrm{~b}$ & 23.7 & 17.5 & 17.8 & 2.5 & 8.2 & 69.7 \\
\hline $11 \mathrm{a}$ & 16.7 & 14.0 & 16.7 & 2.7 & 11.5 & 61.6 \\
\hline $11 \mathrm{~b}$ & 17.1 & 14.6 & 17.5 & 2.9 & 9.7 & 61.9 \\
\hline $12 \mathrm{a}^{\circ}$ & 11.6 & 9.2 & 12.3 & 1.3 & 7.4 & 41.8 \\
\hline $12 \mathrm{~b}$ & 21.7 & 17.2 & 16.5 & 2.4 & 10.3 & 68.2 \\
\hline $\begin{array}{l}\text { smoked } \\
(\mathrm{N}=23)\end{array}$ & $17.9 \pm 4.1$ & $14.2 \pm 3.5$ & $14.9 \pm 3.1$ & $2.3 \pm 0.5$ & $7.7 \pm 2.0$ & $57.0 \pm 12.4$ \\
\hline $\begin{array}{l}\text { non-smoked } \\
(\mathrm{N}=13)\end{array}$ & $2.2 \pm 0.7$ & $1.5 \pm 0.5$ & $1.8 \pm 0.5$ & $1.1 \pm 0.2$ & $2.5 \pm 0.5$ & $9.0 \pm 2.0$ \\
\hline $\begin{array}{l}p \text {-value } \\
\text { (smoked / } \\
\text { non-smoked) }\end{array}$ & $<0.001$ & $<0.001$ & $<0.001$ & $<0.001$ & $<0.001$ & $<0.001$ \\
\hline
\end{tabular}

* Smoking experiment $1 \mathrm{~b}$ was interrupted; the smoking time was only $27 \mathrm{~min}$

${ }^{\circ}$ For the interpretation of experiment 12 the results from experiment $12 \mathrm{~b}$ were used, because the smoking experiment 12 a failed (the maximum of smoke generation temperature was only $370^{\circ} \mathrm{C}$ ). 


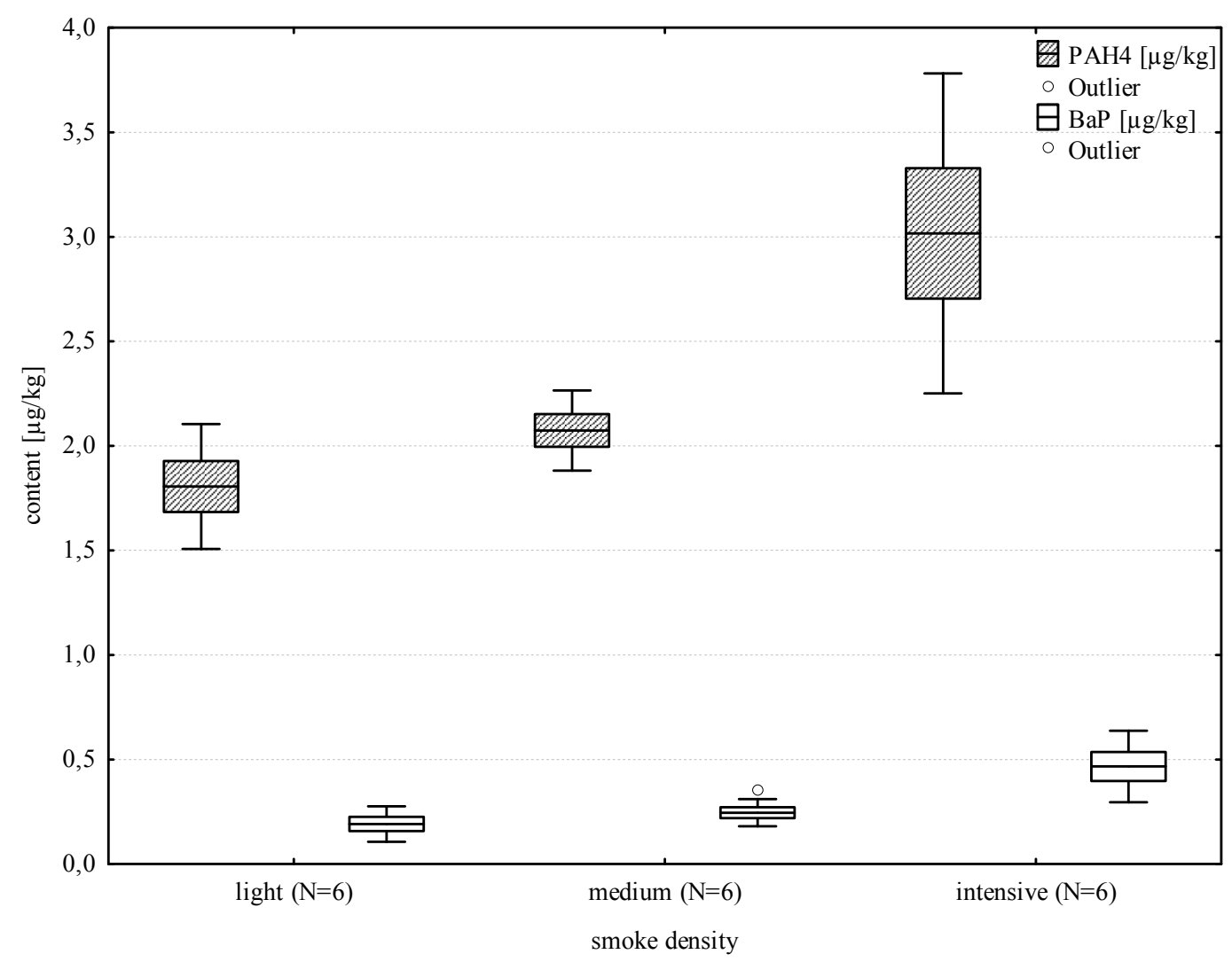

Figure 1. Correlation between smoke density and contents of BaP and PAH4 $[\mu \mathrm{g} / \mathrm{kg}]$ in mini-salamis

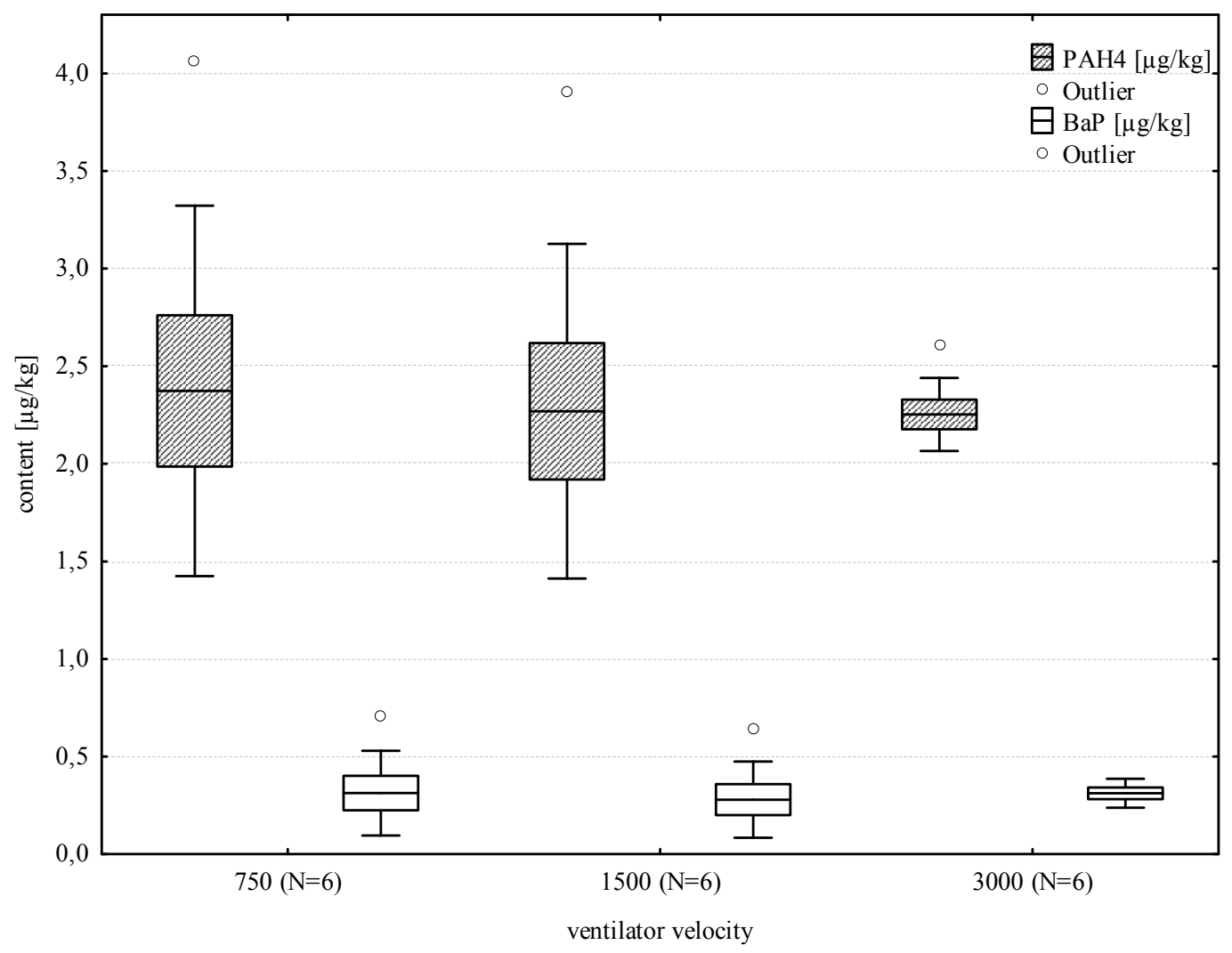

Figure 2. Correlation between ventilator velocity [rpm] and contents of $\mathrm{BaP}$ and PAH4 $[\mu \mathrm{g} / \mathrm{kg}]$ in mini-salamis 


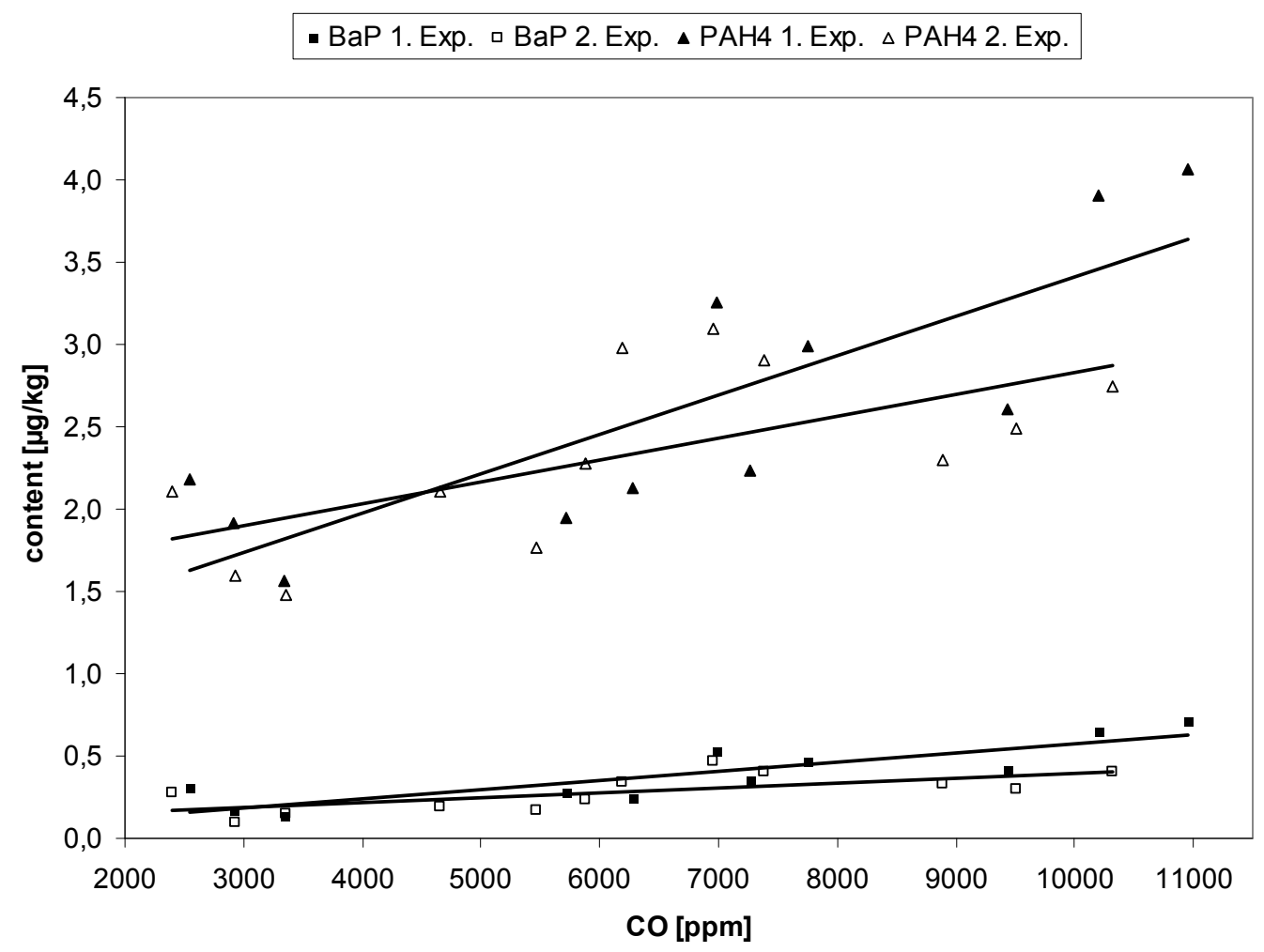

Figure 3. Correlations between maximum concentrations of $\mathrm{CO}$ and contents of $\mathrm{BaP}$ and $\mathrm{PAH} 4[\mu \mathrm{g} / \mathrm{kg}]$ in mini-salamis $(\mathrm{N}=23)$

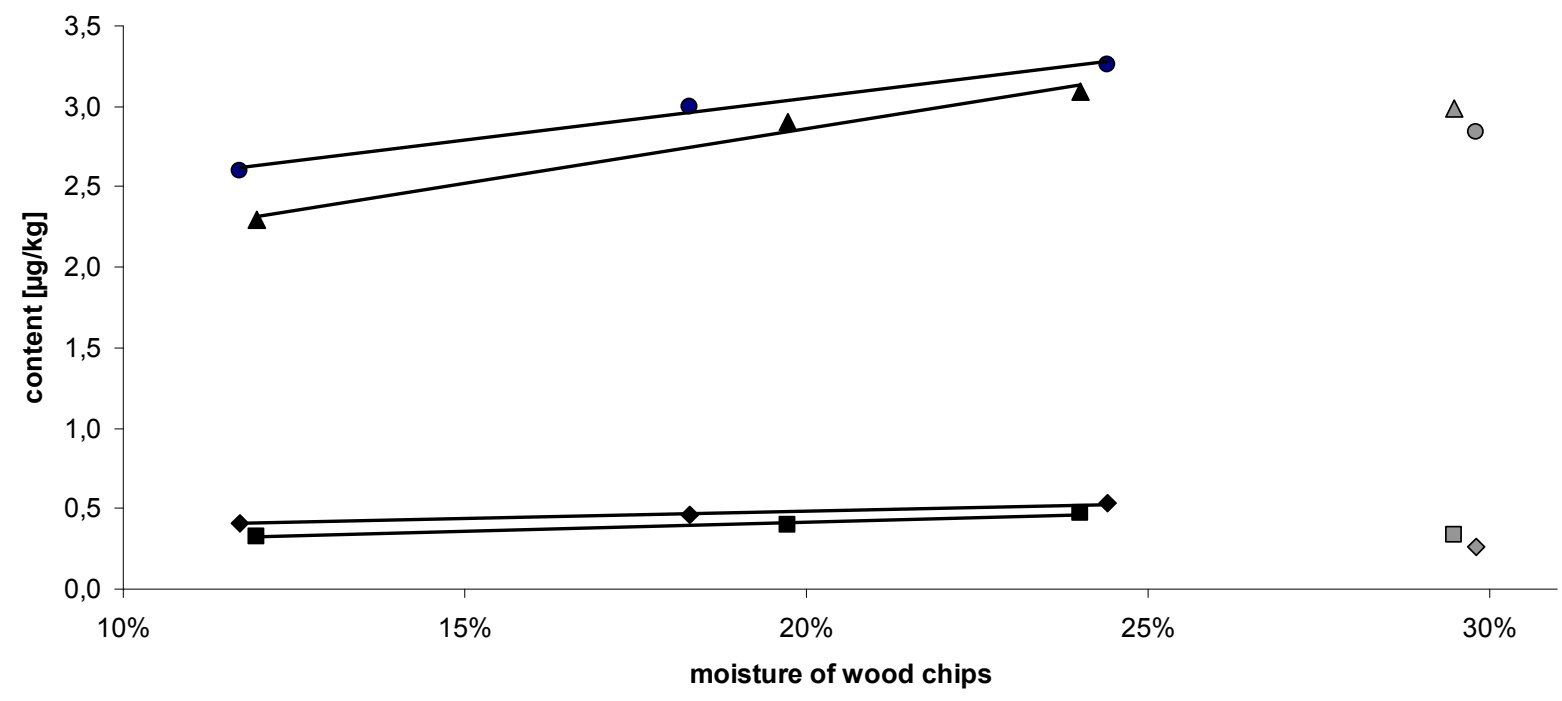

- 1. Exp. PAH4 $\Delta$ 2. Exp. PAH4 • 1. Exp. BaP $\square$ 2. Exp. BaP

Figure 4. Correlations between moisture of wood chips [\%] and contents of $\mathrm{BaP}$ and PAH4 $[\mu \mathrm{g} / \mathrm{kg}](\mathrm{N}=4)$ 


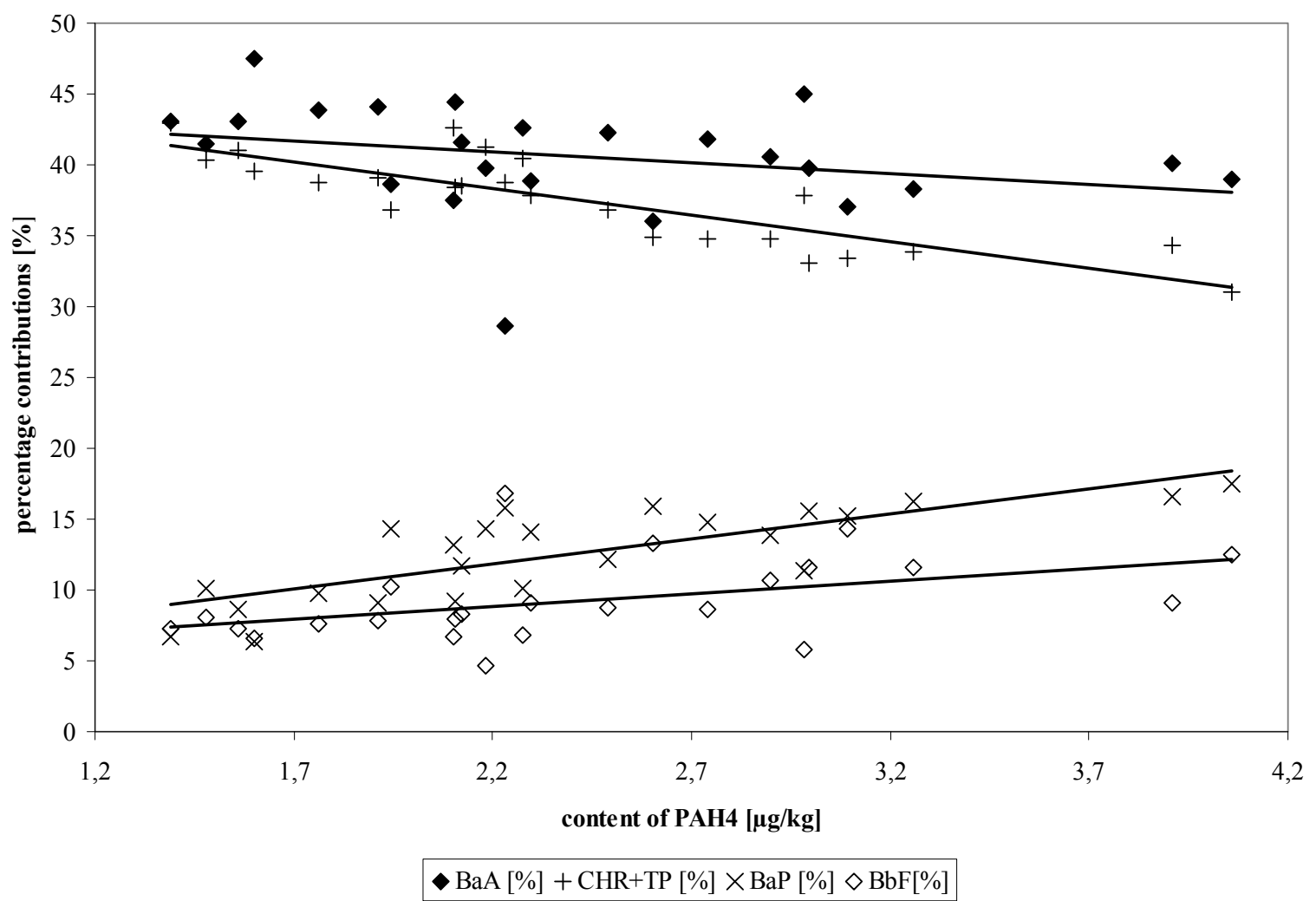

Figure 5. Percentage contributions [\%] of single PAH to the PAH4 content $[\mu \mathrm{g} / \mathrm{kg}]$ in dependence of the PAH4 level $(\mathrm{N}=23)$

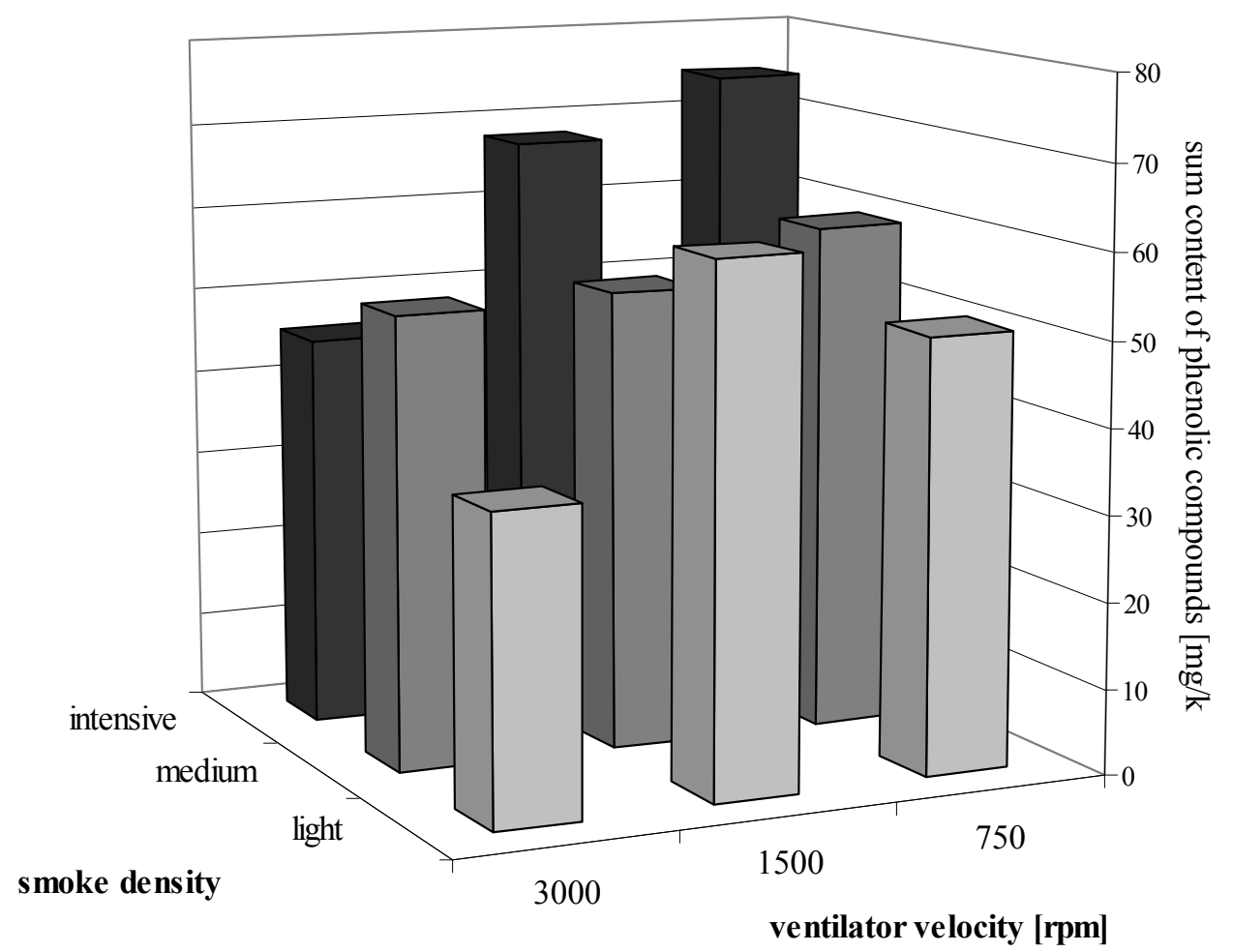

Figure 6. Correlations between smoke density, ventilator velocity [rpm] and sum content of phenolic compounds $[\mathrm{mg} / \mathrm{kg}]$ in smoked mini-salamis 